\title{
Morphological Characteristics of Tall and Dwarf Pearl Millet Isolines
}

\author{
K. N. Rai and W. W. Hanna*
}

\begin{abstract}
Among all the dwarfing genes reported in pearl millet [Pennisetum glaucum (L.) R. Br.], the $d_{2}$ gene has been most extensively utilized in breeding programs. Its effect on morphological characters, however, has not been adequately studied in the past due to lack of isogenic lines. The objective of this research was to study the effect of the $d_{2}$ dwarfing gene on several morphological characters by comparing six pair of tall and dwarf near-isogenic lines (isolines) developed in genetic backgrounds of two diverse composites. Tests conducted on plant and seed characteristics at the ICRISAT Center, Patancheru, India and Tifton, GA, showed that dwarf isolines were shorter but had longer peduncles, longer panicles, narrower panicles, thicker culms, wider leaves, and smaller seeds than their tall counterparts. The differences between tall and dwarf isolines for number of total and effective tillers plant ${ }^{-1}$, leaf sheath length, and time to $\mathbf{5 0} \%$ anthesis were either nonsignificant or inconsistent across locations. Plant height was the only characteristic studied that was not influenced by genetic background. Genetic variation among isolines for effects of the $d_{2}$ gene on numerous characters indicate the gene can be used to advantage by incorporating it into diverse germplasm.
\end{abstract}

$\mathrm{U}$ TILIZATION of dwarfing genes in the development of short-statured cultivars has led to dramatic increases in cereal grain yields (Athwal, 1971). Semidwarf cultivars, as compared to tall ones, respond positively to $\mathrm{N}$ fertilization with yield increases, are less susceptible to lodging under high management conditions, and are more amenable to mechanized production systems. Traditional landrace cultivars and improved cultivars of pearl millet are mostly tall, measuring up to $3 \mathrm{~m}$ under good growing conditions. The discovery of several dwarfing genes (Burton and Fortson, 1966) made it possible to breed improved cultivars with substantial reduction in plant height. The $d_{2}$ dwarfing gene has been most extensively used because it is inherited as a monogenic recessive and it reduces plant height by about $50 \%$ (Burton and Fortson, 1966).

Pearl millet improvement programs for forage or grain production in the USA are based to a large extent on the utilization of the $d_{2}$ dwarfing gene for the development of semidwarf hybrids. Its utilization in the breeding programs located in traditional pearl millet growing regions in India and Africa has been much less extensive. A major effort in the backcross transfer of this gene into the diverse genetic backgrounds of seven tall composites was initiated in 1975 at the International Crops Research Institute for the Semi-Arid Tropics (ICRISAT), India. Comparison of tall recurrent composites with their dwarf versions, derived af-

K. N. Rai, Univ. of Georgia, Coastal Plain Exp. Stn., Tifton, GA 31793 (Permanent address: Cereals Program, ICRISẢ, Patancheru, A.P. 502324, India); and W.W. Hanna, USDA-ARS, Dep. of Agronomy, Coastal Plain Exp. Stn., Univ. of Georgia, Tifton, GA 31793. Cooperative investigations of the USDA-ARS, Univ, of Georgia, and ICRISAT. Approved by ICRISAT JA no. 900 . Received 8 May $1989 .{ }^{*}$ Corresponding author.

Published in Crop Sci. 30:23-25 (1990). ter three backcrosses, showed the $d_{2}$ gene apparently had no adverse effects on grain yield or several of its components (data not shown). Thakare and Murty (1972) also observed that the $d_{2}$ gene had no adverse effects on general combining ability and several developmental traits. These studies, however, were based on the comparisons of tall and dwarf lines or populations that were variable and nonisogenic for the $d_{2}$ gene. The objective of this study was to evaluate the effects of the $d_{2}$ dwarfing gene on several morphological characters in six pairs of near-isogenic lines developed in the genetic backgrounds of two diverse composites.

\section{MATERIALS AND METHODS}

The genetic material in this study consisted of six pairs of near-isogenic lines (hereafter referred to as isolines) in the genetic background of two maturity composites (early composite and medium composite) developed at the ICRISAT Center. The $d_{2}$ dwarfing gene from GAM73 (a synthetic developed in Senegal) had been backcrossed three times into both composites. Seven tall plants in each of five $\mathrm{BC}_{3} \mathrm{~F}_{3}$ progenies segregating for tall and dwarf plants were selfed. The $F_{4}$ progenies were planted in family blocks. One segregating $\mathrm{F}_{4}$ progeny from each family block was selected and seven tall plants were again selfed. The $F_{5}$ progenies were again planted in family blocks to self 7 to 8 tall plants in one segregating $F_{s}$ progeny from each block. This process was repeated until the $F_{8}$ generation when both tall and dwarf plants in one segregating progeny of each block were selfed to identify tall and dwarf isolines in $F_{9}$ progeny tests in 1984. The tall and dwarf components of each isoline pair would theoretically have a high percentage $(98.5 \%)$ of common alleles since they were derived from prolonged selfing of plants heterozygous at the $D_{2} / d_{2}$ locus advanced head-torow in each generation. The six isoline pairs are, however, expected to differ from one another for several genes because five isoline pairs were derived from different $\mathrm{BC}_{3} \mathrm{~F}_{2}$ plants of two composites. Isoline Pairs 5 and 6 were derived from two heterozygous plants of the same $\mathrm{BC}_{3} \mathrm{~F}_{3}$ progeny.

All six pairs of isolines were evaluated in two tests: one conducted at the ICRISAT Center, Patancheru, India during the rainy season of 1987 , and the other conducted at the Coastal Plain Experiment Station, Tifton, GA, in the summer season of 1987. At the ICRISAT Center, the test was planted on 26 June in 4-row plots of 2 -m length with 75-cm spacing between rows. At Tifton, the test was planted on 30 June in 2-row plots of $5-\mathrm{m}$ length with $60-\mathrm{cm}$ spacing between rows of a plot and $120-\mathrm{cm}$ between plots. At both locations, plots were overplanted and thinned 13-d later to single plants with $20-\mathrm{cm}$ spacing between plants at the ICRISAT Center and $30-\mathrm{cm}$ spacing at Tifton. At the ICRISAT Center, $40 \mathrm{~kg} \mathrm{~N}$ and $17.5 \mathrm{~kg} \mathrm{P} \mathrm{ha}^{-1}$ were applied preplant, with another $40 \mathrm{~kg} \mathrm{~N}^{-1}$ side dressed $21 \mathrm{~d}$ after planting. Plots received $14 \mathrm{~kg} \mathrm{~N}, 12.2 \mathrm{~kg} \mathrm{P}$, and $34.9 \mathrm{~kg} \mathrm{~K}$ ha $^{-1}$ preplant at Tifton.

Time to $50 \%$ anthesis (days) was recorded on a plot basis when the main panicle of $50 \%$ of the plants in a plot exserted stigmas. Five plants from the central two rows of each plot at the ICRISAT Center and from both rows of each plot at Tifton were used to determine plant height, peduncle length, panicle length, length of leaf sheath and leaf blade, leaf width, thickness of panicle and culm, and number of tillers 
per plant according to the procedure given in descriptors for pearl millet (IBPGR/ICRISAT, 1981). At the ICRISAT Center, main panicles were harvested and sun-dried for $10 \mathrm{~d}$. Main panicles of the plants used for the above observations at Tifton were covered within a week after anthesis with brown bags. At maturity, bagged panicles were harvested and oven-dried at $37^{\circ} \mathrm{C}$ for 5 to $7 \mathrm{~d}$. Individual panicles from both tests were threshed, and a random sample of 100 seeds from each of five panicles within each of four replications was weighed to determine 100 seed weight. The treatment design for both locations was a split-plot with isoline pairs as main plots, and tall and dwarf isolines within a pair as subplots placed in a randomized complete-block design with four replications. Plot means were used for analyses of variance to determine location effects. A $t$-test was used to detect differences due to the $d_{2}$ gene at each location.

\section{RESULTS AND DISCUSSION}

The differences among isoline pairs and between locations were highly significant $(P<0.01)$ for all the characters indicating that the effect of the $d_{2}$ dwarfing gene was studied in diverse genetic background and environment.

The $d_{2}$ dwarfing gene significantly $(P<0.01)$ reduced the average plant height by $45 \%$ at Tifton and by $38 \%$ at the ICRISAT Center (Table 1). However, mean peduncle length increased by $33 \%$ at Tifton and $22 \%$ at the ICRISAT Center, respectively, due to the $d_{2}$ gene. Peduncle length for one pair at each location (different pair at each location) was of similar length for both the dwarf and tall isolines. Reduction in plant height coupled with general increase in peduncle length due to the $d_{2}$ gene in pearl millet is in contrast to the positive association between these two characters reported in wheat, Triticum aestivum L., (Powell and Schlehuber, 1967), oat, Avena sativa L., (Kolb and Marshall, 1984), and sorghum, Sorghum bicolor (L.) Moench, (Brooks, 1967; Campbell and Cassady, 1969). Some studies in sorghum (Cassady, 1967; Schertz, 1973), however, have reported a neutral or negative association between plant height and peduncle length.

Effect of the $d_{2}$ gene was generally significant $(P<$ 0.01 ) for increasing the mean panicle length, culm diameter, and leaf width, and in decreasing the mean panicle diameter and 100 seed weight in tests at both locations (Table 1). Magnitude of the $d_{2}$ gene effects on these characters, however, showed variation among isoline pairs and between locations. For instance, the panicle length of dwarf isolines was longer than for their tall counterparts in two isoline pairs and equal in four isoline pairs at Tifton. At ICRISAT Center, however, the panicle length of dwarf isolines was longer than for their tall counterparts in three pairs, shorter in one pair and equal in two pairs. Similarly, dwarf isolines had wider leaves than their tall counterparts in three isoline pairs in the Tifton test, but only in one isoline pair in the ICRISAT test.

The dwarf isolines had a significantly longer leaf sheath $(P<0.01)$ and took less time to $50 \%$ bloom $(P<0.05)$ than their tall counterparts in the test at ICRISAT Center (Table 1). These differences, however, were nonsignificant in the Tifton test. The effect of the $d_{2}$ gene on mean number of total tillers plant ${ }^{-1}$ or effective (with inflorescence) tillers plant ${ }^{-1}$ was nonsignificant at both locations. For some pairs, however, the difference between tall and dwarf isolines were significant either at one or both locations, and the direction of change was generally in favor of the dwarfs having more tillers than their tall isolines.

Dwarfing genes may become active during the early stages of plant development and hence could pleiotropically affect numerous other characters. Peduncle length may be one such character. The effect of linkages on peduncle length and other characters, however, cannot be ruled out. The isogenic lines of the present study were produced by inbreeding of plants heterozygous at the $D_{2} / d_{2}$ locus, which would tend to overcome linkages between the $d_{2}$ gene and genes af-

Table 1. Morphological characteristics of tall $(T)$ and dwarf $(D)$ pearl millet isolines.

\begin{tabular}{|c|c|c|c|c|c|c|c|}
\hline \multirow[b]{2}{*}{ Character } & \multirow[b]{2}{*}{ Location } & \multicolumn{2}{|c|}{ Mean } & \multirow[b]{2}{*}{$t$-test } & \multicolumn{3}{|c|}{ No. of isoline pairs where $†$} \\
\hline & & $\mathbf{T}$ & $\mathbf{D}$ & & $\mathbf{T}>\mathbf{D}$ & $\mathbf{T}=\mathbf{D}$ & $\mathbf{T}<\mathrm{D}$ \\
\hline \multirow{2}{*}{ Plant height, cm } & Tifton & 171 & 94 & $* *$ & 6 & 0 & 0 \\
\hline & ICRISAT & 133 & 83 & ** & 6 & 0 & $\mathbf{0}$ \\
\hline \multirow[t]{2}{*}{ Peduncle length, $\mathrm{cm}$} & Tifton & 20.3 & 26.9 & ** & 0 & 1 & 5 \\
\hline & ICRISAT & 22.8 & 27.9 & ** & $\mathbf{0}$ & 1 & 5 \\
\hline \multirow[t]{2}{*}{ Panicle length, $\mathrm{cm}$} & Tifton & 21.9 & 23.4 & ** & 0 & 4 & 2 \\
\hline & ICRISAT & 19.0 & 20.7 & $* *$ & 1 & 2 & 3 \\
\hline \multirow{2}{*}{ Panicle diam., mm } & Tifton & 21.9 & 20.5 & ** & 1 & 5 & 0 \\
\hline & ICRISAT & 19.9 & 19.2 & $* *$ & 2 & 4 & 0 \\
\hline \multirow{2}{*}{ Culm diam., mm } & Tifton & 8.8 & 9.8 & ** & 0 & 4 & 2 \\
\hline & ICRISAT & 7.8 & 8.1 & * & 0 & 5 & 1 \\
\hline \multirow[t]{2}{*}{ Leaf width, mm } & Tifton & 35.9 & 39.3 & $* *$ & 0 & 3 & 3 \\
\hline & ICRISAT & 25.1 & 26.4 & * & o & 5 & 1 \\
\hline \multirow[t]{2}{*}{ Leaf sheath length, $\mathrm{cm}$} & Tifton & 13.6 & 13.7 & NS & 1 & 4 & 1 \\
\hline & ICRISAT & 13.5 & 14.0 & $* *$ & 0 & 4 & 2 \\
\hline \multirow[t]{2}{*}{ Time to $50 \%$ bloom, $d$} & Tifton & 61.3 & 61.5 & NS & 1 & 4 & 1 \\
\hline & ICRISAT & 57.2 & 56.0 & * & 0 & 6 & 0 \\
\hline \multirow{2}{*}{ Total tillers plant ${ }^{-1}$} & Tifton & 6.6 & 7.5 & NS & 0 & 4 & 2 \\
\hline & ICRISAT & 5.2 & 5.2 & NS & 0 & 6 & 0 \\
\hline \multirow[t]{2}{*}{ Effective tillers plant ${ }^{-1} \ddagger$} & Tifton & 3.6 & 4.1 & NS & 0 & 5 & 1 \\
\hline & ICRISAT & 2.6 & 2.8 & NS & 1 & 4 & 1 \\
\hline \multirow[t]{2}{*}{100 seed wt., $g$} & Tifton & 0.68 & 0.62 & $* *$ & 3 & 3 & 0 \\
\hline & ICRISAT & 0.59 & 0.54 & ** & 2 & 4 & 0 \\
\hline
\end{tabular}

*** Statistically significant at 0.05 and 0.01 levels of probability.

+ No. of pairs where differences were statistically significant $(P=0.05)$.

$¥$ Tillers that produced inflorescences. 
fecting other characters. However, close linkages in some studies have been shown to persist much longer than would ordinarily be expected (Harding and Allard, 1965; Tsunewaki and Koba, 1979). Large genetic variation between isoline pairs for the effect of the $d_{2}$ gene on numerous characters indicate that the positive effects of this gene can be exploited to advantage by incorporating it in germplasm of diverse genetic background.

\section{REFERENCES}

1. Athwal, D.S. 1971. Semi-dwarf rice and wheat in global food needs. Annu. Rev. Biol. 46:1-34.

2. Brooks, J.S. 1967. Internode length in height mutants of the sorghum variety Wheatland. Crop Sci. 7:676.

3. Burton, G.W., and J.C. Fortson. 1966. Inheritance and utilization of five dwarfs in pearl millet (Pennisetum typhoides) breeding. Crop Sci. 6:69-72.

4. Campbell, L.G., and A.J. Cassady. 1969. Effects of a single height gene (DW3) on Sorghum bicolor (L.) Moench at l-dwarf and 2-dwarf height levels. Crop Sci. 9:828-830.

5. Cassady, A.J. 1967. Effect of a single height gene (DW, of Sorghum vulgare Pers. on certain culm and leaf blade characteristics. Crop Sci. 7:595-598.

6. Harding, J., and R.W. Allard. 1965. Genetic variability in highly inbred isogenic lines of the Lima bean. Crop Sci. 5:203206.

7. IBPGR/ICRISAT. 1981. Descriptors for pearl millet, p. 34. IBPGR Secretariat, FAO, Rome, Italy.

8. Kolb, F.L., and H.G. Marshall. 1984. Peduncle elongation in dwarf and normal height oats. Crop Sci. 24:699-703.

9. Powell, J.B., and A.M. Schlehuber. 1967. Components of height inheritance of the semidwarf straw character in wheat Triticum aestivum L. Crop Sci. 7:511-516.

10. Schertz, K.F. 1973. Single height-gene effects in hybrids of doubled haploid Sorghum bicolor (L.) Moench. Crop Sci. 13:421423.

11. Thakare, R.B., and B.R. Murty. 1972. Effect of dwarfing genes on combining ability in pearl millet (Pennisetum typhoides (Burmf. and C.E. Hubb). Indian J. Agric. Sci. 42:392-397.

12. Tsunewaki, K., and T. Koba. 1979. Production and genetic characterization of the co-isogenic lines of a common wheat Triticum aestivum cv. S-615 for ten major genes. Euphytica 28:579-592. 